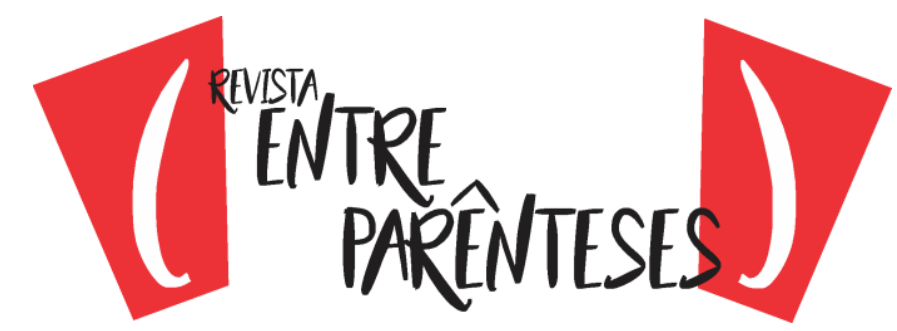

\title{
O NÃO VERBAL NA LEITURA DE MEMES NO ENSINO- APRENDIZAGEM DE ESPANHOL COMO LÍNGUA ADICIONAL
}

\author{
https://doi.org/10.32988/rep.v1n9.1133
}

\author{
Andrea Galvão de Carvalho' \\ Colégio Pedro II \\ andreaprofesp@gmail.com
}

\begin{abstract}
Resumo: Este artigo visa discutir a leitura de memes no ensino-aprendizagem de espanhol como língua adicional com foco no discurso não verbal. Nosso objetivo é pensar possibilidades de explorar o gênero digital meme em atividades de compreensão leitora. Como aporte teórico temos a Análise do Discurso (AD) com base nos estudos de Orlandi $(2009,2012)$ e Pêcheux (2010) e para discutir o não verbal Souza $(2001,2011,2018)$ e Courtine (2013). Para analisar o gênero meme nos baseamos nas autoras Lara $(2017,2020)$ e Candido; Gomes (2015). Nosso estudo nos permite concluir que o meme é um gênero discurso multimodal que possibilita atividades de leitura diversificadas, críticas e, ao mesmo tempo, lúdicas.
\end{abstract}

Palavras-chave: Leitura; Não verbal; Análise do Discurso; Meme.

\section{NON VERBAL IN READING MEMES IN SPANISH LANGUAGE TEACHING-LEARNING AS ADDITIONAL}

\begin{abstract}
This article aims to discuss the reading of memes in teaching-learning Spanish as an additional language with a focus on non verbal discourse. Our goal is to think about possibilities to explore the digital meme genre in reading comprehension activities. As a theoretical contribution we have the Discourse Analysis (AD) based on the studies of Orlandi $(2009,2012)$ and Pêcheux $(2010)$ and to discuss the non verbal Souza $(2001,2011,2018)$ and Courtine (2013). To analyze the meme genre we based on the authors Lara $(2017,2020)$ and Candido; Gomes (2015). Our study allows us to understand the meme as a multimodal genre that allows diverse, critical and at the same time playful reading activities.

Keywords: Reading; Non verbal; Discourse Analysis; Meme.

\section{LO NO VERBAL EN LA LECTURA DE MEMES EN LA ENSEÑANZA-APRENDIZAJE DE ESPAÑOL COMO LENGUA ADICIONAL}

Resumen: Este artículo tiene como objetivo discutir la lectura de memes en la enseñanzaaprendizaje del español como un idioma adicional con un enfoque en el discurso no verbal. Nuestro objetivo es pensar en las posibilidades de explorar el género meme digital en las actividades de comprensión lectora. Como contribución teórica, tenemos el Análisis del Discurso (AD) basado en los estudios de Orlandi $(2009,2012)$ y Pecheux (2010) y para analizar el no verbal Souza $(2001,2011$, 2018) y Courtine (2013). Para analizar el género meme nos basamos en los autores Lara (2017, 2020) y Candido; Gomes (2015). Nuestro estudio nos permite entender el meme como un género multimodal que permite actividades de lectura diversas, críticas y también divertidas.

Palabras clave: Lectura; No verbal; Análisis del discurso; Meme.

\footnotetext{
${ }^{1}$ Doutora em Linguística pela Universidade Federal do Rio de Janeiro (UFRJ).
} 


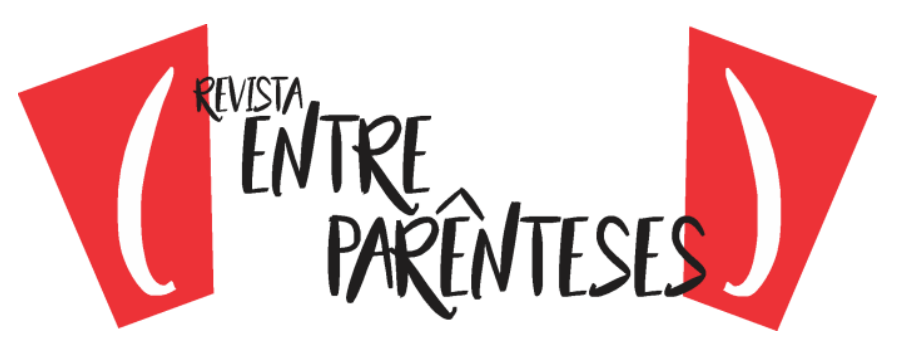

\section{Introdução}

$\mathrm{Na}$ contemporaneidade, as imagens estão por toda a parte exigindo do sujeito que as signifique. São gêneros discursivos e suportes variados e que muitas vezes coadunam a linguagem verbal e não verbal. Nesse contexto, entendemos a necessidade de um olhar mais atento para a leitura imagética, que exige do leitor a compreensão de que o não verbal também é discurso e não apenas uma ornamentação ou mesmo um adereço do verbal. Desta maneira, aprender a ler imagens é conceber que o não verbal significa em si mesmo e não como acessório do verbal.

Neste estudo, nosso objetivo é pensar a leitura do não verbal em memes constituídos pela linguagem verbal e não verbal no ensino-aprendizagem² de língua espanhola. A opção por trabalhar com memes híbridos, que abarquem o verbal e 0 não verbal, é decorrente da nossa experiência em sala de aula, uma vez que diante de textos imagético-verbais os discentes tendem a privilegiar o verbal em detrimento da imagem. O não verbal, então, é visto como mera ilustração e não como discurso a ser lido.

Para o desenvolvimento deste trabalho, pensamos o processo leitor pelo viés da Análise do Discurso (AD) com base nos escritos de Orlandi $(2009,2012)$ e Pêcheux (2010), a leitura do não verbal e de textos imagético-verbais com foco na produção de Souza $(2001,2011,2018)$ e Courtine (2013). Para analisar o gênero digital meme temos as autoras Lara $(2017,2020)$ e Candido; Gomes (2015).

Nas seções seguintes, discutimos a leitura do não verbal e as características que definem o gênero digital meme para, na sequência, pensar o uso de memes nas aulas de espanhol como língua adicional ${ }^{3}$.

\footnotetext{
2 Pensando no processo de ensino indissociável do processo de aprendizagem, utilizamos o termo ensino-aprendizagem com hífen para expressar a interdependência desses dois conceitos (LOPES, 1996).

${ }^{3} \mathrm{~A}$ opção por usar a expressão "língua adicional" se justifica por entendermos que seja uma língua que se soma a outras que o aluno já tem no seu repertório linguístico. Nossa escolha está alinhada a
} 


\section{A leitura do não verbal}

A leitura, em uma perspectiva discursiva, é concebida como um "processo de instauração de sentidos" (ORLANDI, 2012, p. 7) que ocorre entre sujeitos (leitor virtual, autor, etc.), ou seja, é um processo social e histórico mediado pelo texto.

Pelo viés da $A D$, o dizer significa-se na sua relação com a exterioridade e com o já-dito da memória discursiva, como esclarece Orlandi (2012, p.13):

Quando se lê, considera-se não apenas o que está dito, mas também o que está implícito: aquilo que não está dito e que também está significando. E o que não está dito pode ser de várias naturezas: o que não está dito mas que, de certa forma, sustenta o que está dito; o que está suposto para que se entenda o que está dito; aquilo a que o que está dito se opõe; outras maneiras diferentes de se dizer o que se disse e que significa com nuances distintas.

Dessa maneira, ler é saber o que o texto diz e também o que ele não diz, mas que o constitui significativamente. Ou seja, os sentidos que podem ser lidos em um texto não estão necessariamente nele, eles passam pela relação dele com outros textos (existentes, possíveis ou imaginários). É como destaca Orlandi (2012, p.13) "(...) podemos dizer que há relações de sentidos que se estabelecem entre 0 que um texto diz e o que ele não diz, mas poderia dizer, e entre o que ele diz e o que outros textos dizem. Essas relações de sentido atestam, pois, a intertextualidade, isto é, a relação de um texto com outros (...)".

Um discurso é pronunciado a partir de condições de produção dadas (Pêcheux, 2010) que abrange a situação, os sujeitos e a memória. Para Orlandi (2009), as condições de produção referem-se às circunstâncias da enunciação, que, abrangem não somente o contexto imediato, como também o contexto sócio-

estudos como os de Leffa (2014) e Silva Júnior (2018), ao usar "língua adicional" objetivando marcar uma prática pedagógica alinhada a uma educação linguística plural e que percebe as múltiplas realidades locais dos discentes. 


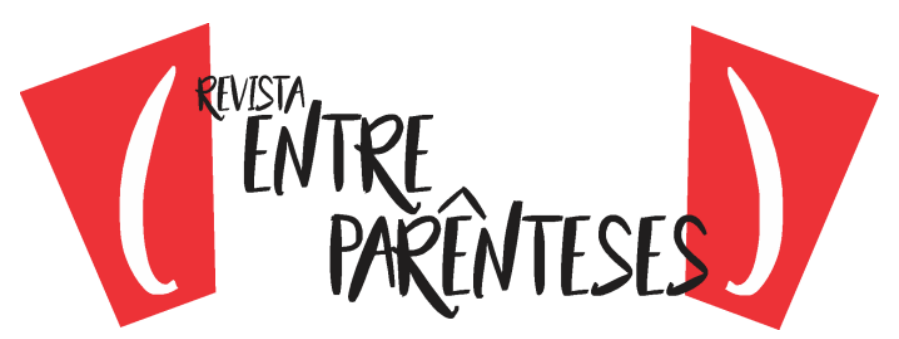

histórico e ideológico. Por conseguinte, segundo a $A D$, deve-se observar como o texto significa em um determinado momento histórico.

A leitura do não verbal pelo viés da Análise do Discurso (AD) considera a imagem discurso que, por conseguinte, significa. Assim, pensar o não verbal pela $A D$ é entender que a imagem em um contexto imagético-verbal não só cumpre um papel na construção do todo, mas também significa de maneira independente. Nos textos híbridos, temos duas linguagens distintas que significam separadamente, mas que associadas são capazes de criar um novo discurso. Não só a estrutura interna da imagem - como os enquadramentos, as cores e a distribuição dos elementos - é relevante para a leitura imagética, mas, principalmente os elementos sócio-políticos e culturais que a compõem. É como defende Souza (2011, p. 20), "o trabalho de interpretação da imagem, como na interpretação verbal, vai pressupor também a relação com a cultura, o social, o histórico, com a formação social do sujeito".

Com base no conceito de intericonicidade, proposto por Courtine (2013), entendemos que a leitura do não verbal vai exigir do leitor a realização de conexões com outras imagens já vistas, ou mesmo imaginadas. Nessa mesma linha de reflexão, Souza (2001) estabelece o termo policromia como dispositivo de análise "que permite, ao se interpretar a imagem, projetar outras imagens, cuja materialidade, não é da ordem da visibilidade, mas da ordem do simbólico e do ideológico. Da ordem do discurso" (SOUZA, 2018, p.23).

A autora define policromia como uma rede de elementos visuais, implícitos ou silenciados, que possibilitam diferentes interpretações do texto não verbal.

Com isso, se diz que as imagens não são visíveis, tornam-se visíveis a partir da possibilidade de cada um projetar as imagens possíveis, que necessariamente, não compõem a estrutura visual do texto não verbal em si, mas que compõem a rede de imagens mostradas, indiciadas, implícitas, metaforizadas ou silenciadas. (SOUZA, 2018, p. 23) 


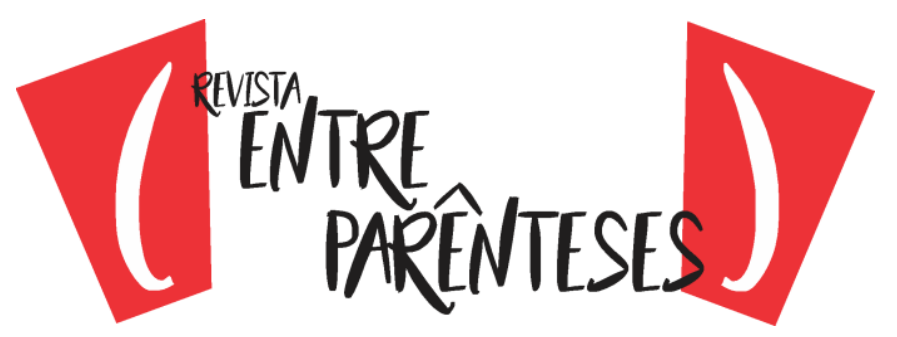

A concepção de que uma imagem opera transculturalmente, independente dos contextos sociais, e que, portanto, todos entenderão o mesmo conteúdo na mesma imagem expõe o mito da transparência da imagem e da evidência do sentido icônico (SOUZA, 2001). Nesse quesito Vieira (2007, p. 15) explica que

As culturas produzem imagens próprias e sob esse enfoque apenas é que podemos interpretá-las. Cada nação constrói imagens e símbolos particulares. Nos Estados Unidos, as torres gêmeas simbolizavam o poder político e econômico norte-americano. Os povos constroem imagens afirmativas ou negativas a respeito de sua nação ou de outras nações. Para um estrangeiro, as imagens do Brasil são provavelmente as do carnaval e do futebol.

A falácia de que a imagem é universalmente acessível a qualquer um do mesmo modo reforça a ideia de que todos sabem ler imagens e que não é necessário um olhar voltado para o ensino-aprendizagem do imagético. Na verdade, entendemos a existência de uma necessidade de ativação da percepção e do interesse do sujeito-leitor para o não verbal, principalmente quando a linguagem imagética se coaduna com a linguagem verbal.

Se pensamos a leitura do não verbal em textos em língua adicional, parece-nos relevante destacar que a imagem, por não ser universalmente compreensível, vai exigir do leitor, que está ausente do contexto de produção do texto, o conhecimento de fatos, de dados que circulam na cultura da língua adicional e que, muitas vezes, não estão explicitados na imagem a ser lida. Como exemplo, destacamos a leitura do meme da imagem 1, que tem como pano de fundo a série norte-americana Os Simpsons. 

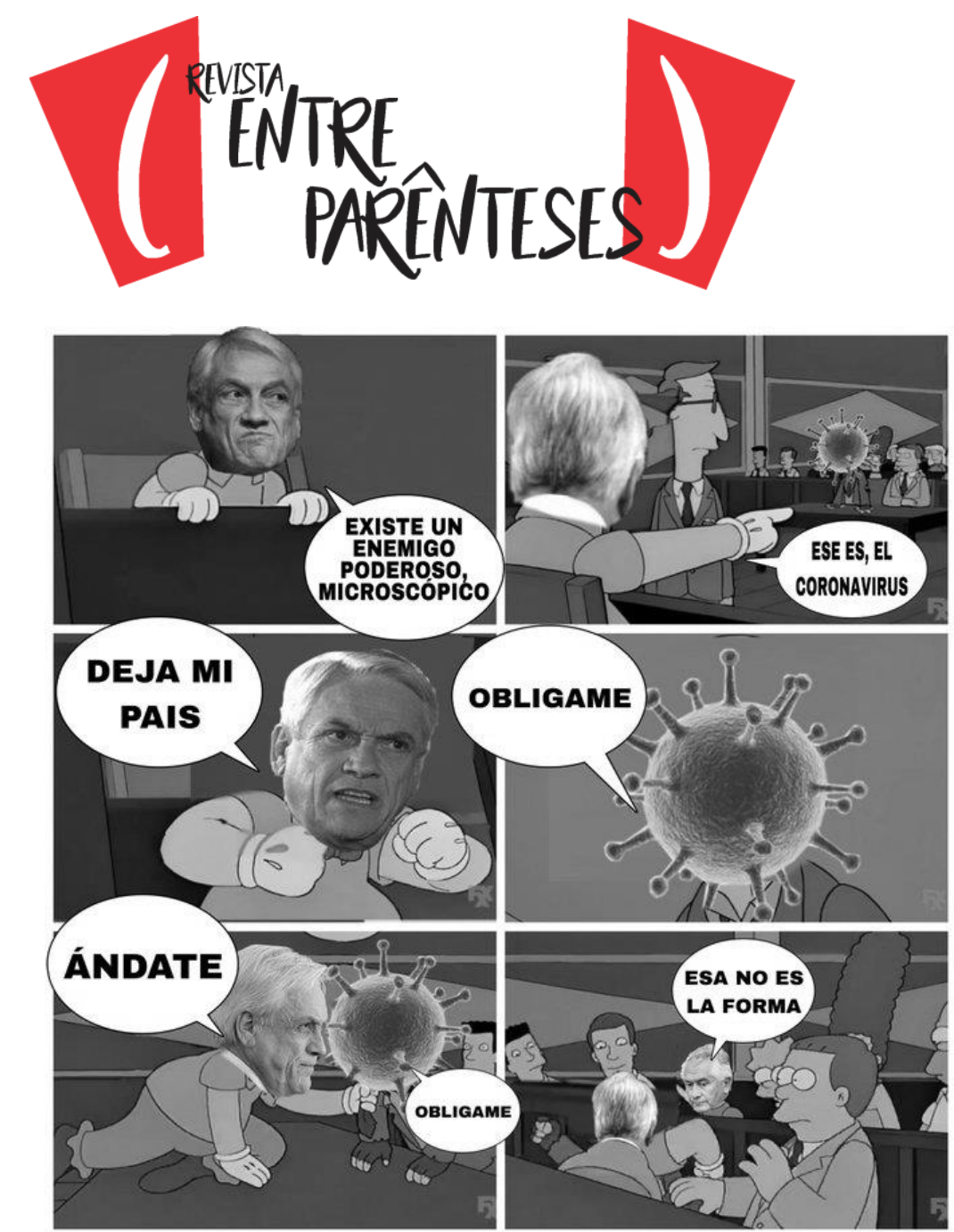

Imagem 1: Presidente do Chile e coronavírus ${ }^{4}$

A representação imagética do coronavírus é transcultural em virtude da pandemia e, portanto, é mais provável de ser identificada pelo leitor por sua ampla circulação na mídia. Por sua vez, a imagem do homem "brigando" com o vírus vai exigir que o leitor conheça Sebastián Piñera, presidente do Chile. Podemos concluir que, se o não verbal do meme não forma parte da memória visual do discente, este não será capaz de construir sentido para a imagem 1. Caberia ao docente elaborar práticas que permitissem ao aluno adquirir o conhecimento imagético e também de condições de produção pertinentes ao meme.

Uma possibilidade seria um trabalho de pesquisa a partir da fonte do texto, onde o leitor vai encontrar que o meme faz referência a uma notícia

\footnotetext{
$4 \quad$ https://www.perfil.com/noticias/internacional/sebastian-pinera-recurrio-dialogo-con-coronavirus-lepido-como-presidente-que-nos-deje-tranquilos-se-vaya.phtml
} 


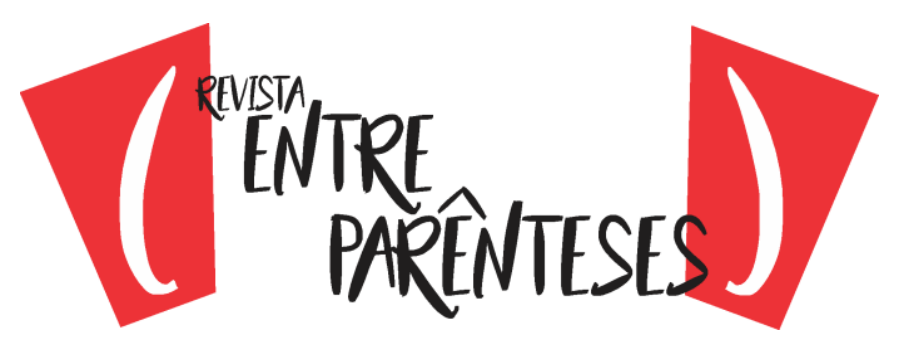

internacional sobre um diálogo de Sebastián Piñera com o coronavírus. Da fonte, também pode-se extrair a informação de que ele poderia ser um presidente, mas não de onde. A pesquisa permite não só identificar o não verbal que não esteja na memória do leitor, como resgatar a situação ironizada no meme envolvendo o presidente do Chile.

Em um contexto de ensino-aprendizagem de línguas, o trabalho com gêneros discursivos multimodais como são os memes possibilita que o docente proponha atividades que dirijam a atenção do discente para a leitura do não verbal. O texto multimodal "é aquele que recorre a mais de uma modalidade de linguagem ou mais de um sistema de signos ou símbolos (semiose) em sua composição" (ROJO; BARBOSA, 2015 p.108). No quesito multimodalidade, destacamos Nascimento et al. (2011, p. 530), que afirmam que

(...) não existem textos monomodais ou monosemióticos, já que, mesmo em textos predominantemente verbais, utilizamos recursos visuais, tais como tipografia e formatação. Por exemplo, a distribuição do texto em colunas, bem como o uso de linhas e marcas gráficas são utilizados para evidenciar a distribuição da informação em blocos temáticos e orientar a leitura. Já recursos tipográficos, como fonte, negrito ou uso de cor, servem para salientar determinados elementos ou criar efeitos de sentido particulares: por exemplo, fontes serifadas, como a Times New Roman, podem remeter a contextos jornalísticos.

Discutir a construção de sentido em textos que consideram múltiplas linguagens vai exigir que examinemos, ainda que brevemente, os conceitos de letramentos e multiletramentos.

A concepção de letramento surge em meados dos anos de 1980 para caracterizar os usos e práticas sociais de leitura e escrita. "Como são muito variados os contextos, as comunidades, as culturas, são também muito variados as práticas e os eventos letrados neles circulantes" (ROJO; MOURA, 2019, p.18) e com o entendimento dessa variedade o conceito de letramento passa para o plural. Os autores Rojo e Moura (2019) destacam que trabalhar com os letramentos na escola 


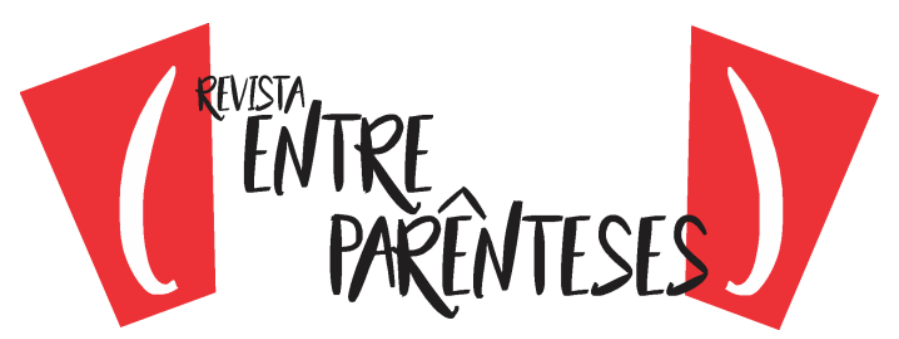

consiste em criar eventos que integrem os alunos em práticas de leitura e escrita socialmente relevantes.

No final do século 20, com o desenvolvimento das novas mídias digitais, os textos deixam de ser essencialmente escritos e passam a ser compostos por múltiplas linguagens (escrita, oral, imagem, vídeos etc.). Com os textos multimodais, nasce o conceito de multiletramentos visando atender as práticas letradas multiculturais e multimodais que utilizam diferentes mídias e distintas linguagens. Cani e Coscarelli (2016) apontam dois pilares relacionados à construção de significados e que são a base da concepção de multiletramentos:

O primeiro é a diversidade social, ou seja, a variabilidade das convenções do significado em diversos momentos culturais, sociais ou de domínio específico. (...) O segundo pilar diz respeito à multimodalidade (...) Esses textos exigem do leitor habilidades para lidar com a multiplicidade de linguagens, semioses e modos para deles fazer sentido. (CANI; COSCARELLI, 2016, p.19)

Nossa proposta, neste trabalho, é o uso de memes para o desenvolvimento de um trabalho de leitura do não verbal em textos multimodais em língua espanhola. Entendemos que a utilização de memes em sala de aula permite não somente o desenvolvimento de práticas de multiletramentos, mas também discussões que abarcam aspectos sócio-políticos e culturais; seja da língua materna do discente, seja de língua estrangeira, ou mesmo na intersecção de ambas.

\section{O trabalho com memes imagético-verbais}

O vocábulo meme surge originalmente na área da biologia, quando Richard Dawkins, no livro "O gene egoísta" de 1976, ao pensar sobre replicadores culturais, define o termo, a partir da raiz grega mimeme, para referir-se ao que se copia e que é compartilhado e disseminado por sujeitos nos espaços de interação.

No campo das Ciências da Linguagem, o termo meme caracteriza tudo aquilo que viraliza. "Um meme é em resumo, qualquer conceito propagado através da internet, independentemente da forma, podendo ser, por exemplo, uma imagem, 


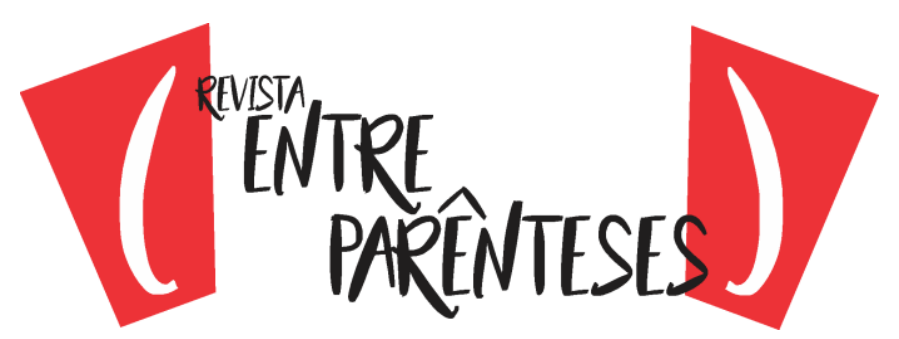

um vídeo, um áudio ou até mesmo uma palavra ou uma frase" (CANDIDO; GOMES, 2015: 1295).

Entendemos o meme como um gênero digital efêmero que se caracteriza por ressignificar imagens, acontecimentos e frases sempre com um tom de humor por meio de enunciados verbais, não verbais e verbo-visuais. "O estilo do meme também é constituído, muitas vezes, por citação e paródia, ou seja, em diálogo com outros textos e outras imagens, podendo citá-los de forma direta ou indireta, ressignificando-os em um novo acontecimento" (LARA, 2017, p.12).

Fenômeno típico da internet, os memes não são apenas compartilhados nas mais distintas mídias virtuais, são também reapropriados pelos usuários que o ressiginificam e transformam o seu conteúdo em outro meme.

Virais, os memes, geralmente, têm sua temporalidade limitada em virtude do uso de temáticas que versam sobre o cotidiano imediato.

Os acontecimentos, temas (no sentido bakhtiniano) destes enunciados, podem ser de conhecimento compartilhado, seja de todo o mundo, ou então de uma nação, estado ou cidade, de um grupo social, ou mesmo de apenas dois sujeitos, o que reacentua a importância do diálogo nas interações com a linguagem, pois a resposta do leitor depende dos elos que ele estabelecerá na cadeia de enunciados para produção de sentidos. A arquitetônica do meme dá-se nessa relação com a memória; o acontecimento é novo, mas sempre em relação com a memória. (LARA, 2017, p.11)

No contexto escolar, sabemos que o gênero meme faz parte do universo cultural do alunado, entretanto entendemos que o fato de estar familiarizado, de conhecer o gênero multimodal não faz do discente um leitor crítico, capaz de construir significado a partir do meme lido. É papel, portanto, da escola oferecer ao aluno práticas de letramentos e multiletramentos que permitam a formação de leitores proficientes em gêneros distintos.

O gênero discursivo meme se conforma através da paródia do discurso de outro, utilizando a ironia, a sátira, a imitação e a amplificação como elementos de comunicação. Na leitura do gênero digital, o leitor var precisar estabelecer as 


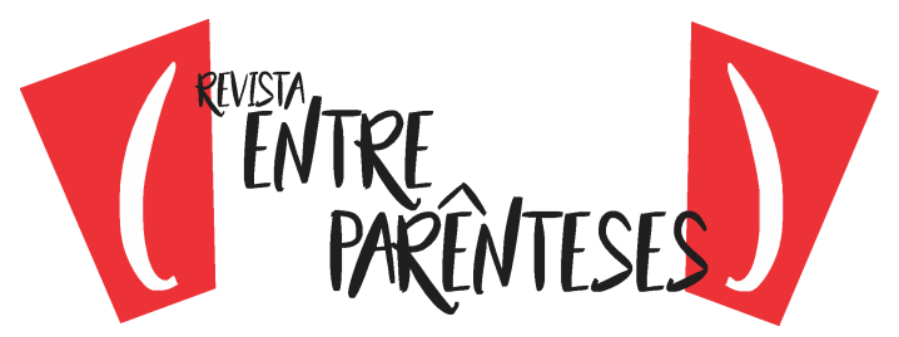

relações de humor que se estabelecem e se apresentam em forma de crítica social, política e/ou cultural sobre acontecimentos atuais.

O uso de memes em sala de aula permite a reflexão sobre variadas questões políticas, sociais e culturais, inclusive em trabalhos interdisciplinares. No caso da aula de língua adicional, é uma oportunidade de reconhecer e discutir temas relacionados à diversidade linguística e cultural.

Para poder utilizar os memes em sala de aula, o docente vai precisar elaborar o seu próprio material didático, pois, como uma das principais características do gênero é a sua efemeridade, poucos são aqueles que podem ser utilizados no livro didático sem ficarem descontextualizados.

Dentre os diferentes tipos de memes, este artigo trabalha com os memes compostos por uma imagem sem movimento acompanhada de um enunciado verbal. Nos memes verbo-visuais, a imagem e o texto verbal são extraídos de contextos diferentes que na configuração final adquirem uma significação única e própria. Nesse contexto, as atividades pensadas com os memes podem ser utilizadas visando trabalhar o olhar do leitor para entender o discurso não verbal como enunciado a ser lido.

\section{Lendo memes em língua espanhola}

Os memes multimodais selecionados, neste artigo, para discutir a leitura do não verbal apresentam o verbal e o imagético como discursos independentes e interdependentes, ou seja, o leitor precisa interpretar ambos os discursos individualmente e também estabelecer a relação que se constitui entre a linguagem verbal e não verbal na formação de um discurso único.

O processo leitor e, consequentemente, de significação exige do sujeito a compreensão das condições de produção do escrito. São as redes de memória constituídas pelas imagens e pela linguagem verbal que associadas permitem a ressignificação do discurso apresentado no meme. 


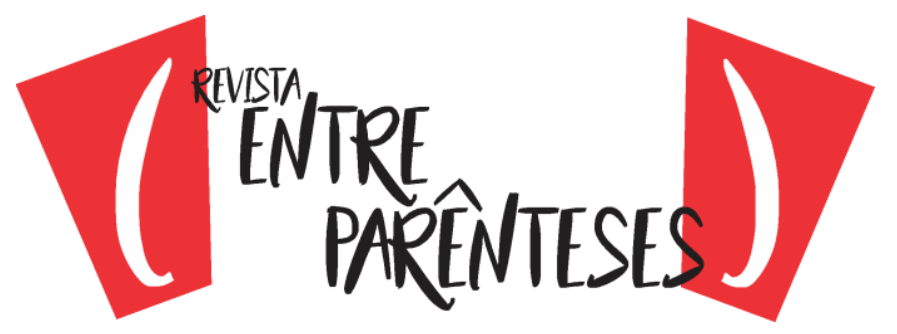

Iniciamos com um meme que exemplifica uma das possíveis características memética: a efemeridade do discurso. O meme, criado no dia 30 de junho de 2018, aborda a eliminação da Argentina da Copa do Mundo de Futebol.

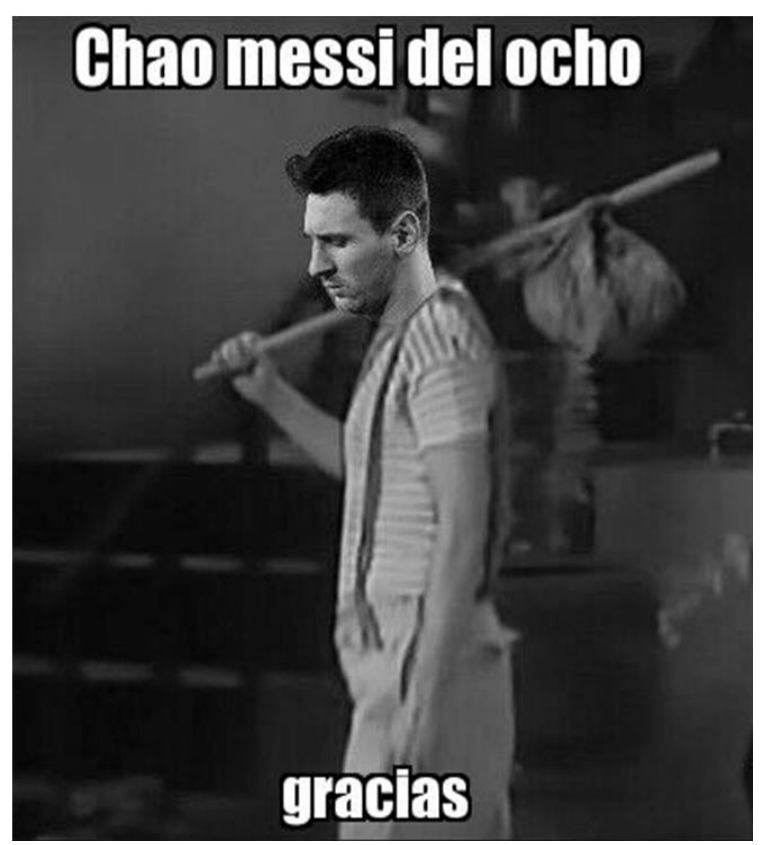

Imagem 2: Meme Messi voltando para casa ${ }^{5}$

$\mathrm{Na}$ imagem, temos o principal jogador argentino, Leonel Messi, vestido com as roupas do personagem Chaves de uma série mexicana de sucesso (Chavo del Ocho). Temos a reprodução de uma cena do episódio intitulado "O ladrão da vila", na qual o personagem, após ser acusado de ladrão, junta os seus pertences e se prepara para deixar a vila onde mora. No caso do futebolista, que na montagem teve o seu rosto colocado sobre a face do personagem, não há acusações sobre ele, na verdade, há um agradecimento ("gracias”) pelo feito à seleção argentina durante a Copa.

Como proposta didática, entendemos a necessidade de ressaltar o humor associado ao carinho com o ídolo nacional. Trabalhar a comparação feita pelo meme entre Messi e Chaves, buscando estabelecer as características que o personagem do seriado pode estar emprestando ao jogador é possível através do uso do

${ }^{5}$ http://generadordememesonline.com/meme/rryclp 


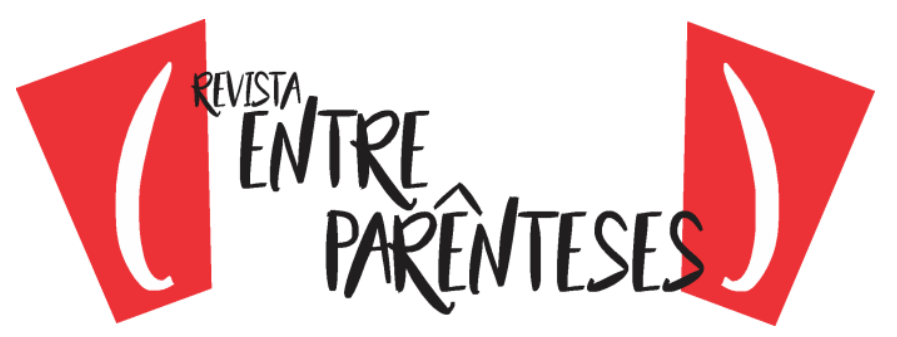

episódio usado como imagem do texto. Os alunos podem assistir ao episódio visando identificar os elementos que permitam uma comparação entre os personagens com base nas condições de produção do meme criado no período da Copa do Mundo.

A imagem 3 refere-se ao mesmo acontecimento e faz humor com a saída da seleção portuguesa de futebol no mesmo dia da seleção argentina. $\mathrm{Na}$ imagem, dois dos maiores jogadores do mundo e principais estrelas de suas seleções apertam as mãos ao "som" do refrão da música de Enrique Iglesias e Servando Primera "Duele el corazón", de 2016.

As práticas de leitura sob o viés da $A D$ devem exigir que o leitor estabeleça relações com o contexto, com outros discursos e com outros textos. Assim, o diálogo do meme com a música pode ser explorado de maneira que o discente seja capaz de definir tal relação ao escutar a música e ao conhecer o contexto de produção do meme.

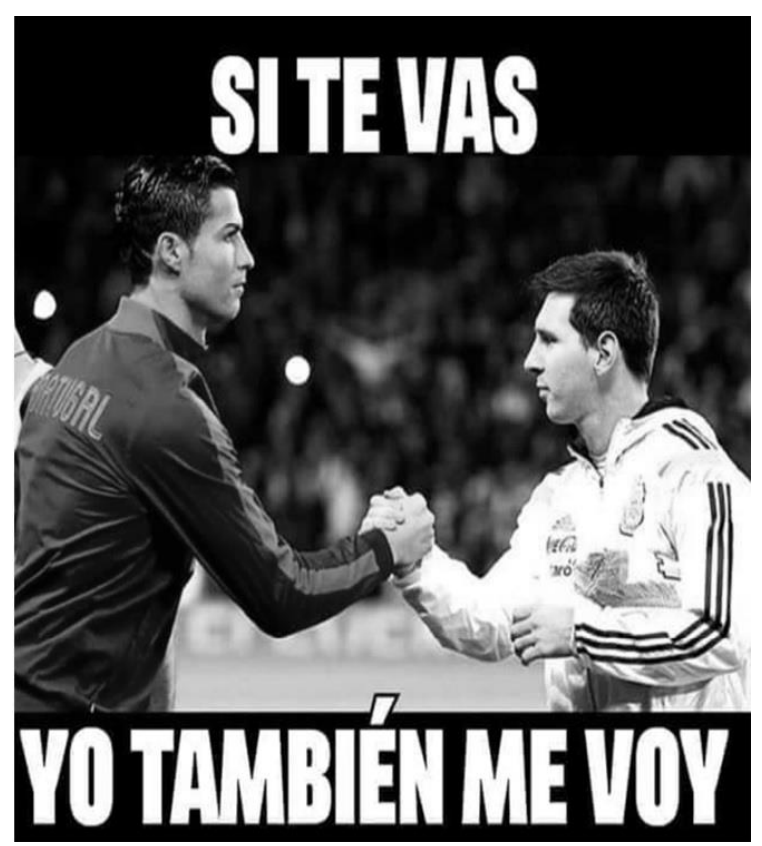

Imagem 3: meme Messi e Cristiano ${ }^{6}$

6 https://peopleenespanol.com/celebridades/memes-eliminacion-leo-messi-cristiano-ronaldo-enmundial-rusia-2018/ 


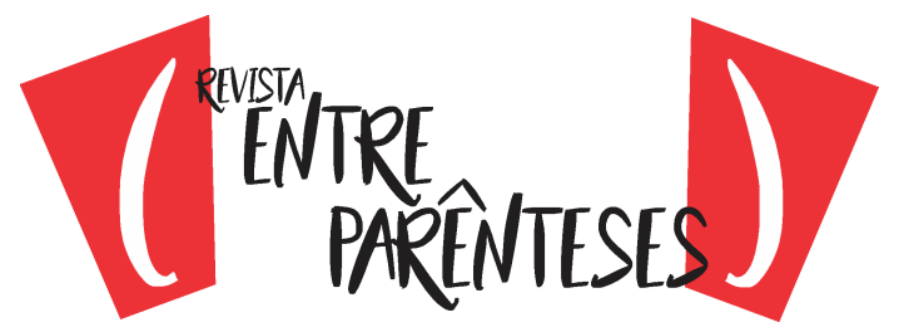

Ambos memes reproduzidos nas imagens 2 e 3 são representativos da importância de se considerar o período de publicação do meme na elaboração de atividades de leitura com o gênero discursivo. No momento de seleção do texto, o docente deve ter os conteúdos que visa trabalhar em sala e identificar se o fato de 0 meme estar deslocado do período temporal seria um impedimento para utilizá-lo.

No caso do uso de memes deslocados temporalmente é necessário que o docente resgate o contexto sócio-histórico do período de produção dos enunciados. Para elaboração de atividades, ambos memes possibilitam o trabalho com outros gêneros discursivos. $O$ meme 2 pode ser trabalhado com o episódio do seriado supracitado, enquanto o terceiro meme motiva o estudo da música que compõe o discurso verbal do enunciado memético.

O meme da imagem 4 é de 2016, entretanto, o docente, ainda que precise esclarecer as suas condições de produção, inclusive por colocar em foco um político pouco conhecido fora do contexto mexicano, pode utilizá-lo visando um trabalho voltado para a temática do bullying escolar e/ou do preconceito linguístico.

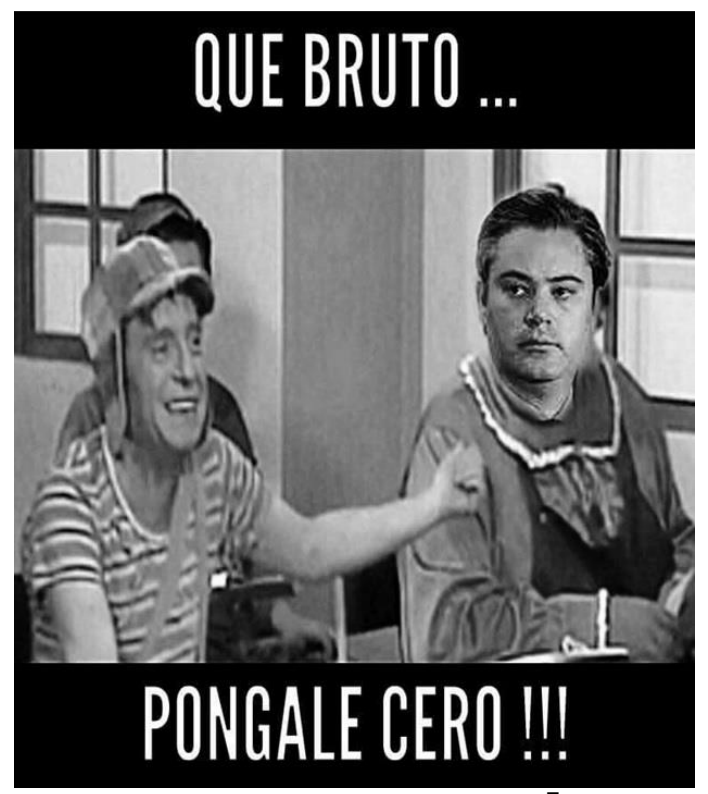

Imagem 4: póngale cero7

7 http://tamaulipasenlared.com/2016/11/15/tras-correccion-de-nina-a-nuno-usuarios-de-redes-loridiculizan-con-memes 


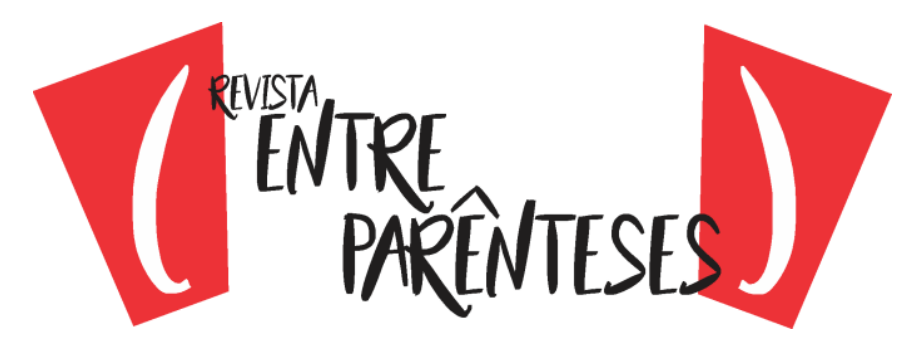

Temos retratado no meme da imagem 4 uma situação vivida por Aurelio Nuño Mayer, titular da Educação Pública do México durante a Feira Internacional do Livro Infantil e Juvenil. No evento, Aurelio Nuño foi corrigido por uma criança ao pronunciar "ler" e não "leer". A imagem, por sua vez, é um frame do seriado mexicano Chaves, que mostra, em um contexto de sala de aula, o personagem do próprio Chaves sentado ao lado do personagem Nhonho, que teve o seu rosto substituído pelo do ministro Mayer. No seriado, Nhonho era um menino de 8 anos muito estudioso, mas que, às vezes, utilizava vocábulos equivocados para se expressar. No meme, Chaves o chama de "burro" (Que bruto...) e pede que o professor "dê zero" (Póngale zero!!!) para Nhonho.

Nossa sugestão é apresentar aos alunos a situação ironizada no meme através de uma notícia ${ }^{8}$ que contextualize o ocorrido. Ao conhecer o fato e identificar o humor realizado a partir de um "erro" linguístico do político em questão, o foco passa a ser discutir sobre variedade linguística, norma padrão da língua, o discurso de inteligência e/ou burrice inatas; temas presentes no nosso cotidiano e que acabam por reforçar o discurso de bullying presente no meme.

O discente deve estar atento para o fato de alguns memes apresentarem enunciados não verdadeiros, as fake news, ou disseminarem pensamentos preconceituosos como nos parece ter ocorrido no meme da imagem 3. Entendemos, entretanto, que tais textos podem e devem ser utilizados, pois possibilitam a discussão de temas fundamentais para a formação de cidadãos na contemporaneidade.

Ressaltamos que os aspectos linguísticos também podem e devem ser pauta de atividades. No meme em questão, o uso do Imperativo Afirmativo, posição do pronome complemento e o vocábulo "bruto" que tem sentido diferente para a língua portuguesa são temas que podem ser abordados.

\footnotetext{
${ }^{8}$ https://www.milenio.com/politica/ler-leer-corrige-nina-aurelio-nuno
} 


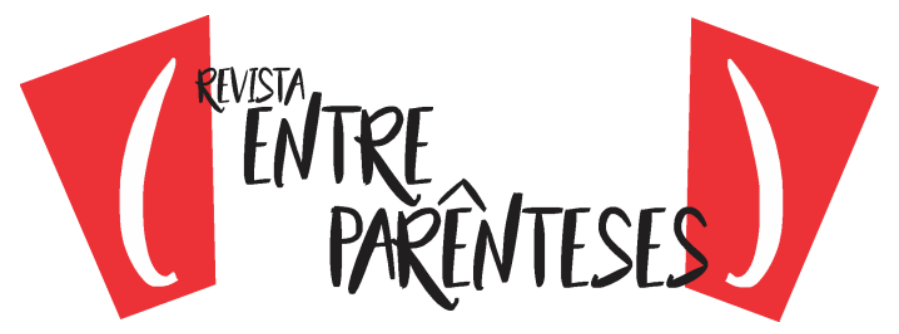

O meme da imagem 5 tem na língua a principal fonte de humor e curiosidade para falantes de português. O conhecimento do vocábulo "cachorro", que, assim como "bruto" da imagem 4, é um heterossemântico, é necessário para que o leitor possa construir o significado do texto que se estrutura na composição do verbal com o imagético. Quando o leitor entende "cachorro" como o animal mamífero e não como um filhote, ele tem na imagem a confirmação da sua significação. Ou seja, a linguagem verbal pode induzir ao erro.

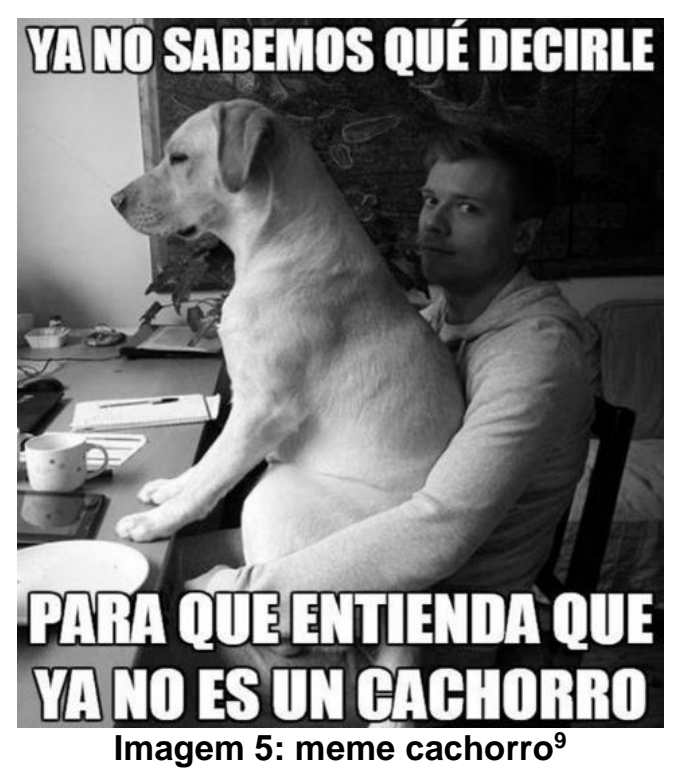

Já para os falantes de espanhol, o humor do meme está centrado exclusivamente no não verbal ao mostrar um cachorro enorme no colo do dono como se este ainda fosse um filhote. Linguagem verbal e não verbal caminham juntas na construção do significado do enunciado memético.

$\mathrm{Na}$ imagem 6, temos um meme que se apropria do gênero discursivo rótulo de embalagens para fazer a sua crítica política e econômica ao governo da Venezuela.

9https://www.facebook.com/elcampitorefugio/photos/a.303858495223.329167.303147460223/101606 $53304775224 /$ ?type=3\&theater 

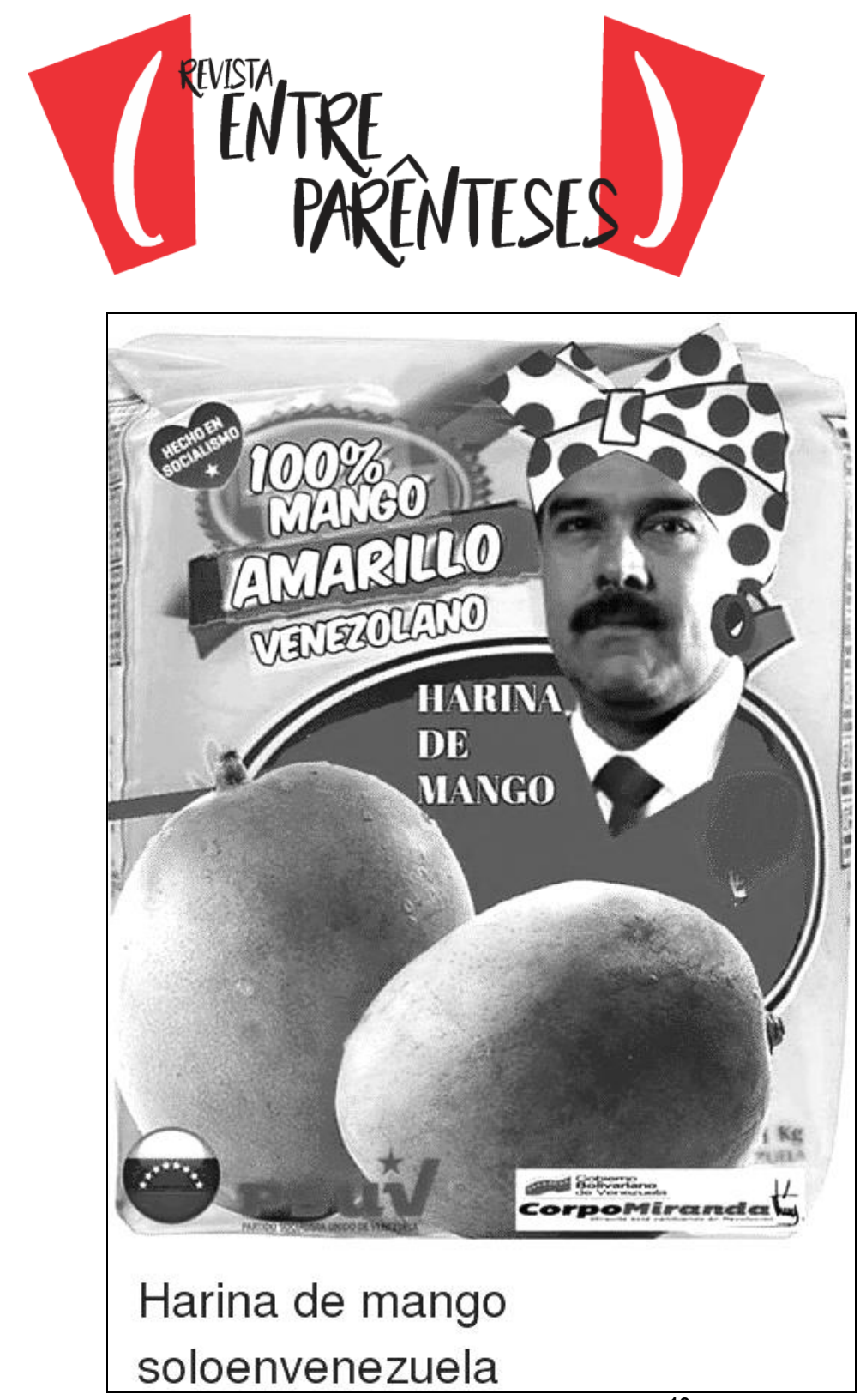

Imagem 6: meme Venezuela ${ }^{10}$

Vemos o rosto do presidente da República da Venezuela, Nicolás Maduro, no pacote de uma conhecida farinha de milho pré-cozido no país. Entretanto, na embalagem, lê-se farinha de manga ("harina de mango") uma vez que a farinha de milho, principal ingrediente da "arepa" (um dos pratos típicos da culinária venezuelana) estava escassa.

$\mathrm{Na}$ leitura do não verbal, além do presidente substituindo a mulher com turbante na embalagem do produto, temos outros símbolos representativos do governo atual e do partido que ocupa o poder, o Partido Socialista Unido de

10 http://www.arepadigital.com/los-memes-y-la-dieta-del-mango-en-venezuela/ 


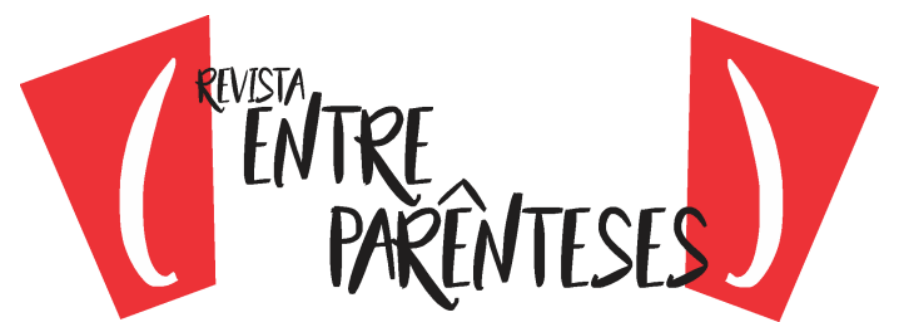

Venezuela (PSUV). Na imagem 6, podemos identificar o logo do partido, a bandeira do país, um coração perpassado pela frase "hecho en socialismo" ("feito no socialismo"), logo da empresa criada pelo governo ("corpomiranda").

Podemos ver, então, uma paródia que critica a substituição de um produto típico da culinária venezuelana e que indica que o regime político-econômico do país é o responsável por impor aos cidadãos novos hábitos alimentares.

O meme permite não só discutir a política instaurada no país pelo governo de Maduro, em um trabalho interdisciplinar, mas também aspectos culturais da gastronomia de uma sociedade, além de trabalhar a leitura de gêneros discursivos que se apropriam de formas discursivas utilizadas por outros gêneros, como foi o caso do meme que utilizou elementos do gênero publicitário para elaborar seu discurso.

A Imagem 7 apresenta um meme datado que vai exigir do leitor o conhecimento do momento sócio-histórico de produção do gênero digital.

Si el 2020 fuera un tobogán

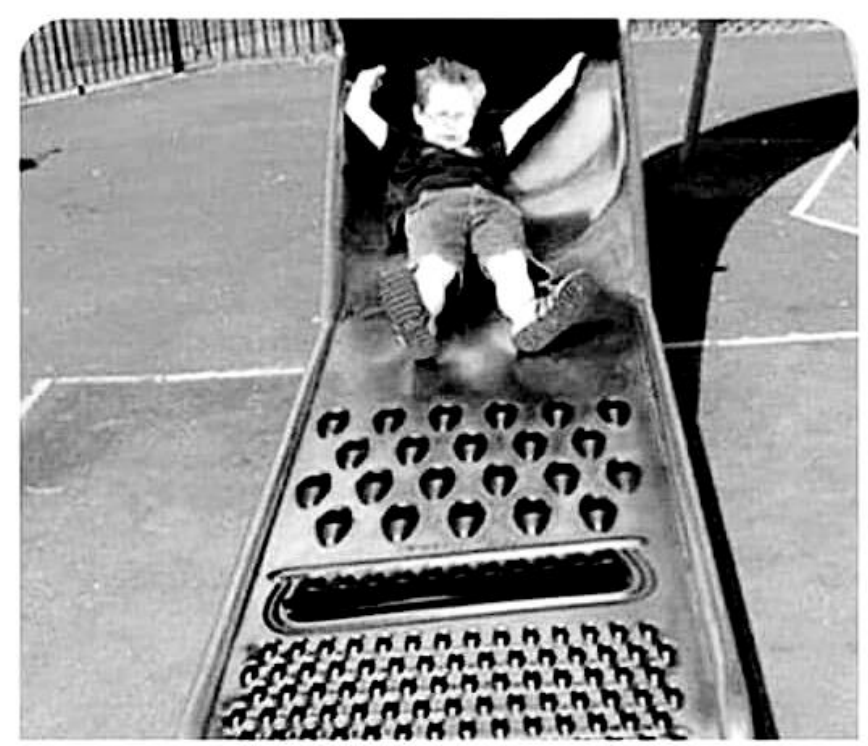

Imagem 7: meme escorregador ${ }^{11}$

${ }^{11} \mathrm{https}: / /$ atopisimo.com/fotos/tobogan-resbaleta-2020-rallador-de-queso/

Revista (Entre Parênteses)

Número 9, Volume 1, 2020 - ISSN 2238-4502 


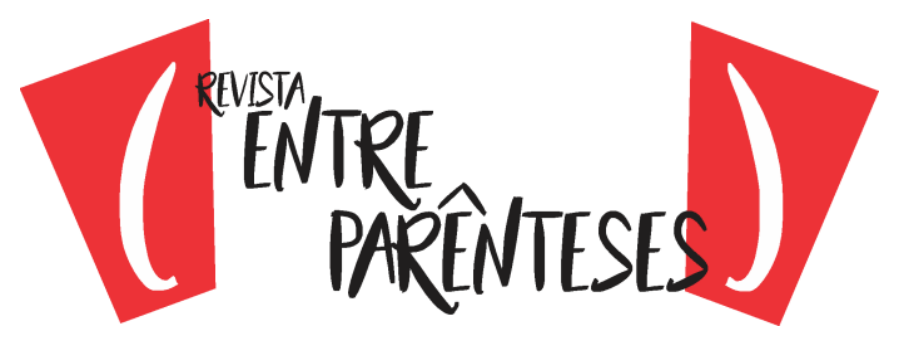

Assim, saber da doença respiratória aguda, COVID-19, provocada pelo coronavírus, que surgiu na China em dezembro de 2019 e foi declarada pandemia pela Organização Mundial da Saúde (OMS) em 11 de março de 2020 explica e contextualiza o meme.

Entretanto, como uma das características do meme é ressignificar, o que acaba por permitir que um único meme origine vários outros, podemos ter uma reformulação do enunciado verbal e a aplicação da mesma ideia do meme "original" a outros anos difíceis como o de 2020.

Como proposta de atividade, o meme da figura 8 é um exemplo de um texto adequado para ser usado como um motivador, buscando preparar o aluno para discutir questões pertinentes acerca da pandemia, inclusive em aulas interdisciplinares com disciplinas como biologia, geografia ou mesmo matemática. Ao explorar o meme, o docente tem, no texto da imagem 7 , a oportunidade de destacar características do gênero multimodal como o uso da ironia, a importância da imagem para a construção do sentido e a necessidade do conhecimento das condições de produção do texto.

Vários são os memes, inúmeras são as possibilidades de atividades não só de leitura, mas também de elaboração de memes. E no meio de tantas possibilidades, é papel do docente guiar o alunado com propostas que permitam a formação de cidadãos e leitores mais críticos e reflexivos.

\section{Breve conclusão}

$\mathrm{Na}$ atualidade, a leitura de imagens é parte do nosso cotidiano, estamos inseridos em contextos que exigem cada vez mais a leitura de textos imagéticos e híbridos (que coadunam linguagem verbal e não verbal). Diante desse cenário, acreditamos que 0 uso de gêneros discursivos verbo-visuais no ensino- 


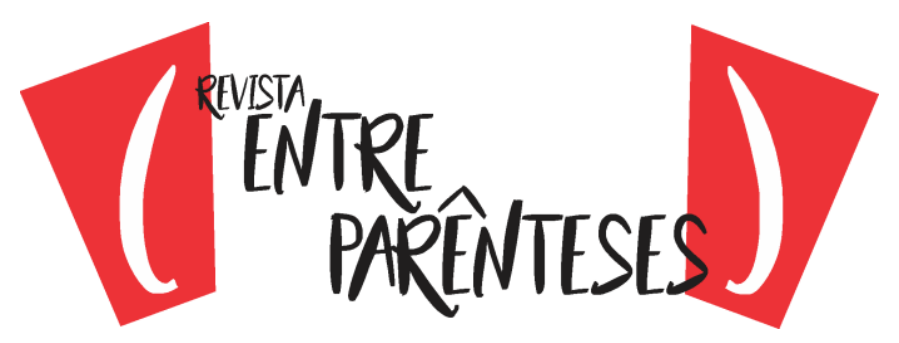

aprendizagem de línguas seja uma ferramenta indispensável para a formação de leitores críticos.

No presente artigo, escolhemos os memes como gênero discursivo de circulação digital para discutir as possibilidades de elaboração de atividades para discentes de espanhol como língua adicional. O objetivo é que o aluno possa ter um olhar mais atento para o enunciado imagético e que a imagem não seja só ornamento para a linguagem verbal, mas seja lida como discurso.

Nos memes, encontramos protestos sociais, denúncias políticas e críticas culturais, temas que permitem a elaboração de atividades de leitura bastante diversificadas e que, em um contexto de sala de aula de língua adicional, possibilita trabalhar aspectos que, poucas vezes, os livros didáticos conseguem abordar. Principalmente, porque os enunciados que apresentam temas efêmeros acabam ficando datados quando utilizados no livro didático.

O tom de humor com que os memes apresentam as suas críticas sociais e políticas permitem aulas mais lúdicas e descontraídas ao mesmo tempo que oferecem a oportunidade de reflexões profícuas e estudos interdisciplinares.

\section{Referências}

CANDIDO, Evelyn Coutinho Rother; GOMES, Nataniel dos Santos. Memes - uma linguagem lúdica. Revista Philologus, Ano 21, N 63 - Supl: Anais da X CNLF. Rio de Janeiro: CiFEFiL, set./dez.2015.

CANI, J. B.; COSCARELLI, C. V. Textos multimodais como objetos de ensino: reflexões em propostas didáticas. In: KERSCH, D. F.; COSCARELLI, C. V.; CANI, J. B. Multiletramentos e multimodalidade: ações pedagógicas aplicadas a linguagem. Campinas: Pontes, 2016.

COURTINE, J-J. Decifrar o corpo - Pensar com Foucault. Petrópolis, RJ: Editora Vozes, 2013.

DAWKINS, Richard. O gene egoísta. São Paulo: Companhia das Letras, 2007. 


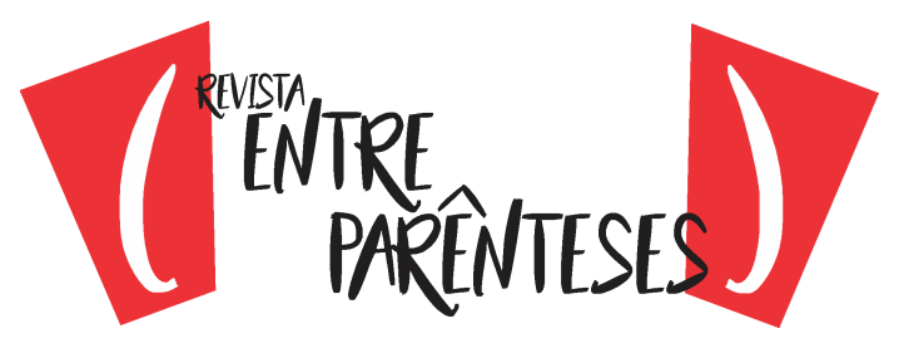

LARA, M. T. A. A presença de memes em aulas online de língua materna: considerações sobre multiletramentos e práticas de leitura de enunciados verbovisuais. Miguilim - Revista Eletrônica do Netlli, Crato, v. 6, n. 1, p. 05-23, jan.-abr. 2017.

LARA, Marina Totina de Almeida; MENDONCA, Marina Célia. O meme em material didático: considerações sobre ensino/aprendizagem de gêneros do discurso. Bakhtiniana, Rev. Estud. Discurso, São Paulo , v. 15, n. 2, p. 185-209, Jun. $2020 \quad$ Disponível em: $<<$ http://www.scielo.br/scielo.php?script=sci arttext\&pid=S2176-

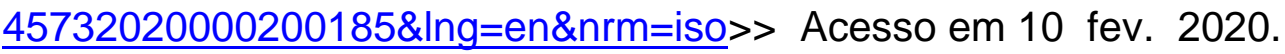

LEFFA, Vilson J.; IRALA, Valesca Brasil (Org.). Uma espiadinha na sala de aula: ensinando línguas adicionais no Brasil. 1. ed. Pelotas: Educat, 2014.

LOPES, Antonia Osima. Relação de Interdependência Entre Ensino e Aprendizagem. In: VEIGA, Ilma, P. Alencastro (org). Didática: o ensino e suas relações. Campinas: Papirus, 1996.

NASCIMENTO, R. G; BEZERRA, F. A. D; HEBERLE, V. M. Multiletramentos: iniciação à análise de imagens. Linguagem e Ensino, Pelotas, v. 14, n. 2, p. 529-552, jul./dez. 2011.

ORLANDI, Eni Pulcinelli. Discurso e Leitura. 8ª ed. São Paulo: Cortez, 2012.

Análise de Discurso: princípios e procedimentos. $8^{\mathrm{a}}$ ed. São Paulo: Pontes, 2009.

PECHÊUX, Michel. Análise automática do discurso (AAD-69). In: GADET \& HAK (org). Por uma análise automática do discurso: uma introdução à obra de Michel Pêcheux. Campinas: UNICAMP, 2010a.

ROJO, Roxane; BARBOSA, Jaqueline P. Hipermodernidade, multiletramentos e géneros discursivos. São Paulo: Parábola, 2015.

Parábola, 2019. 


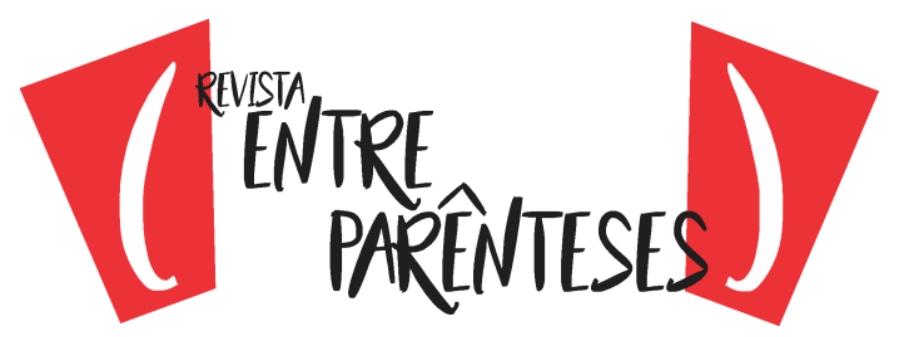

SILVA JÚNIOR, A. F. Lenguas adicionales: ¿qué implica el uso de dicho término?. São Paulo: Santillana, 2018 (Texto em blog).

SOUZA, T. C. C. de. Perspectivas da análise do (in)visível: a arquitetura discursiva do não verbal. In: RUA [online]. ํㅡ. 24. Volume 1 - junho/2018.

. Imagem, textualidade e materialidade discursiva. In: Análise de Discurso no Brasil: pensando o impensado sempre. Uma homenagem a Eni Orlandi. 1 ed. Campinas: Editora RG, 2011, v.1, p. 387-400.

A análise do não verbal e os usos da imagem nos meios de comunicação. Ciberlegenda, no 06, 2001.

VARGENS, D. P. M.; FREITAS, L. M. A. . Ler e escrever: muito mais que unir palavras. In: BARROS, Cristiano Silva de; COSTA, Elzimar Goettenauer de Marins (Org.). Coleção Explorando o Ensino Espanhol: ensino médio.: , 2011, v. 16, p.

VIEIRA, J. A. Novas perspectivas para o texto: uma visão multissemiótica. In: VIERA, J. A. et al. Reflexões sobre a língua portuguesa - uma abordagem multimodal. Petrópolis: Editoras Vozes, 2007.

Recebido em: 21/04/2020

Aceito em: 28/07/2020 